DaGley, S. (1954). J. gen. Microbiol. 11, 218-227.

\title{
Dissimilation of Citric Acid by Aerobacter aerogenes and Escherichia coli
}

\author{
By S. DAGLEY \\ Department of Biochemistry, University of Leeds
}

\begin{abstract}
SUMMARY: When Aerobacter aerogenes was harvested from citrate + mineral salt media in which the concentration of carbon source limited the crop, citridesmolase activity of cells was high but was absent when growth ceased with citrate in excess. These differences were abolished by disintegration of the cells. The ability of Escherichia coli to dissimilate citrate was measurable only after growth in a medium containing peptone, citrate and glucose: when the latter was consumed activity fell and was revived by further glucose additions. Differences in activity of such cells were not abolished by their disintegration. Cells lost their activity when incubated for $30 \mathrm{~min}$. with phosphate buffer or with the citrate + mineral salt medium that supports growth of $A$. aerogenes. $E$. coli grown at the expense of glucose in a mineral salt medium + citrate, did not utilize citrate for growth during the first day and no citridesmolase activity could be detected, but when subsequently tested in a medium which permitted development of activity, higher activities were reached by cells that had grown in presence of citrate. $E$. coli grown in peptone + citrate + glucose medium possessed little oxaloacetate decarboxylase; by the action of disintegrated cells, citrate gave rise to equimolar quantities of keto-acid, chiefly oxaloacetic acid.
\end{abstract}

A citrate +mineral salt medium will support growth of most strains of Aerobacter aerogenes but not of Escherichia coli (Koser, 1924). The extraction of 'condensing enzyme' from $E$. coli (Stern \& Ochoa, 1951) and the demonstration (Lara \& Stokes, 1952) that dried cells oxidized citric acid indicated a function for this compound in the economy of $E$. coli and suggested that inability to metabolize citrate might be attributed to its failure to pass into the cells. From studies of conditions affecting the ability of $A$. aerogenes to dissimilate citrate, and from experiments with cell-free extracts, Dagley \& Dawes $(1953 a, b)$ concluded that dissimilation to oxaloacetate and acetate (Brewer \& Werkman, 1939) occurred by an inducible (adaptive) mechanism that was not identical with reversal of citrate synthesis in the tricarboxylic acid cycle. Gillespie \& Gunsalus (1953), working with Streptococcus faecalis, arrived at similar conclusions and gave the name 'citridesmolase' to the enzyme responsible for citrate cleavage. These results suggest that although difficulties of cell permeability may be sufficient to account for the inability of $E$. coli to oxidize citrate, failure to dissimilate this compound may be due also to lack of citridesmolase development in cells grown in citrate + mineral salt media. Lominski, Conway, Harper \& Rennie (1947) and Vaughn, Osborne, Wedding, Tabachnick, Beisel \& Braxton (1950) reported disappearance of citrate from cultures of $E$. coli supplied with various nutrients, while Grunberg-Manago \& Gunsalus (1953) prepared extracts of the organism which dissimilated citrate. In the present work the nutritional requirements for citridesmolase development in $\boldsymbol{E}$. coli have been studied and compared 
with those for $A$. aerogenes. Further, an attempt has been made to evaluate the contribution of cell permeability to whole-cell activity by conducting experiments with suspensions of disintegrated cells.

\section{METHODS}

The organisms used were Aerobacter aerogenes NCTC 418 and Escherichia coli NCTC 5928. In a mineral salt medium containing citrate as sole source of carbon, the concentration of the citrate may limit the crop of $A$. aerogenes, or citrate may remain unconsumed when growth has ceased (Dagley $\&$ Dawes, $1953 a$ ). Media used contained: $\mathrm{KH}_{2} \mathrm{PO}_{4}, 50 \mathrm{~g}$; $\left(\mathrm{NH}_{4}\right)_{2} \mathrm{SO}_{4}, 20 \mathrm{~g}$.; $\mathrm{MgSO}_{4}$. $7 \mathrm{H}_{2} \mathrm{O}, 2 \mathrm{~g}$.; made to $10 \mathrm{l}$. with distilled water, with the addition of either $70 \mathrm{~g}$. or $200 \mathrm{~g}$. sodium citrate dihydrate to provide limiting or excess citrate respectively. The medium for growth of $E$. coli contained: $\mathrm{KH}_{2} \mathrm{PO}_{4}, 90 \mathrm{~g}$; peptone (Difco), 56 g.; $\mathrm{MgSO}_{4} \cdot 7 \mathrm{H}_{2} \mathrm{O}, 2 \mathrm{~g}$.; sodium citrate dihydrate, 50 g.; glucose, $10 \mathrm{~g}$.; water to $10 \mathrm{l}$. All media were adjusted to $\mathrm{pH} 7 \cdot 0$ by addition of $5 \mathrm{~N}-\mathrm{NaOH}$. Batches of both organisms were grown at $37^{\circ}$ in 10 l. flasks filled to the neck and were harvested in a Sharples supercentrifuge. Suspensions of disintegrated cells were prepared by crushing $c .10 \mathrm{~g}$. frozen cell paste in a Hughes (1951) press previously cooled to $-14^{\circ}$. Crushed cells taken up in $40 \mathrm{ml}$. phosphate buffer ( $\mathrm{pH} \mathrm{7.0)}$ gave rather viscous suspensions which, when active cells of both species were used, after centrifugation at $7000 \mathrm{~g}$ to remove debris provided translucent cell-free extracts capable of dissimilating citrate. The abilities of cells to dissimilate citrate (citridesmolase activity) may be compared by measurement of initial rates of keto-acid production by suspensions of standard turbidity (Dagley \& Dawes, 1953a). This procedure was adopted in the present work, with slight modifications due to the fact that $E$. coli was not in general so active as $A$. aerogenes. Samples were taken from cultures and the bacteria removed by centrifugation: they were well drained but not washed before testing since activity may be considerably decreased by washing. The volume of any sample was such that the final concentration of cells was $2 \times 10^{9} / \mathrm{ml}$. when the bacteria were resuspended in test medium (sodium citrate dihydrate $2.1 \% ; \mathrm{KH}_{2} \mathrm{PO}_{4}, 0.5 \% ; \mathrm{MgSO}_{4} .7 \mathrm{H}_{2} \mathrm{O}, 0.04 \%$;

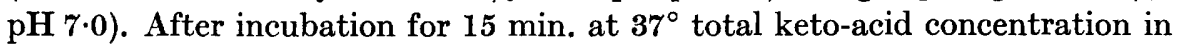
the supernatant after centrifugation was determined by the method of Friedemann \& Haugen (1943). Pyruvate and oxaloacetate were extracted as their 2:4-dinitrophenylhydrazones (Dagley, Fewster \& Happold, 1952). The $R_{F}$ values of the oxaloacetate and $\alpha$-ketoglutarate derivatives in the butanol/ ethanol/ammonium carbonate buffer mixture used by these authors are similar, 0.25 and 0.20 respectively; the glycine $/ \mathrm{NaOH}$ solvent of Virtanen, Miettinen \& Kunttu (1953), which separates them more readily, was also used. Chromatography of 2:4-dinitrophenylhydrazones is complicated by the existence of stereoisomers (Isherwood \& Cruickshank, 1954), although 'satellite' spots were detected in the above solvents only in the case of pyruvate; accordingly, no experiments are described in which identification rests solely on $R_{F}$ values. 
Glucose concentrations were determined by the Somogyi (1937) method; total nitrogen in $3 \mathrm{ml}$. samples of suspensions of disintegrated cells by a modification of the Kjeldahl procedure (Varley, 1954); growth was followed turbidimetrically as described by Dagley, Dawes \& Morrison (1950). Conventional Warburg techniques were used as described by Umbreit, Burris \& Stauffer (1945).

\section{RESULTS}

\section{Citridesmolase activity of Aerobacter aerogenes: comparison of whole and distintegrated cells}

Dagley \& Dawes (1953a) showed that cells were active when they were harvested during the period of logarithmic growth in a citrate mineral salt medium, or when growth had ceased through citrate depletion. Cells from a culture in its stationary phase with excess citrate were inactive. This loss of ability to dissimilate citrate was now studied. A suspension of disintegrated cells was prepared from an active batch $\left(0 \cdot 8 \mu\right.$ mole keto-acid $/ 2 \times 10^{9}$ cells $/ 15 \mathrm{~min}$. $)$ and its nitrogen content determined. Dilutions $(1 / 5,1 / 10$ and $1 / 100)$ were made in phosphate buffer ( $\mathrm{pH} 7 \cdot 0$ ), $2.5 \mathrm{ml}$. of each dilution added to separate volumes of citrate test medium in $6 \times 1$ in. Pyrex tubes and after shaking to disperse the suspensions they were incubated for $15 \mathrm{~min}$. at $37^{\circ}$. Equal volumes of $10 \%(\mathrm{w} / \mathrm{v})$ ice-cold trichloroacetic acid were then added, the precipitates filtered off and the keto-acid concentrations of the filtrates determined. The experiment was repeated with cells which had no detectable activity harvested from medium containing excess citrate. In Fig. 1 it is seen that keto-acid production was proportional to the amount of suspension. This relationship ceased at high values, an increase from 164 to $820 \mu \mathrm{g} . \mathrm{N} / \mathrm{ml}$. $(\mathbf{4 1 5} \%)$ only gave a $24 \%$ increase in keto-acid production. In Fig. 1 are also shown results for disintegrated cells grown with aeration in a glucose+ mineral salt medium; such preparations when tested in the Warburg respirometer were able to oxidize citrate but were unable to dissimilate it appreciably. It is clear from Fig. 1 that the large difference in citridesmolase activity shown by cells from media containing different concentrations of citrate was largely abolished when the cells were disintegrated.

\section{Influence of the growth medium on citridesmolase activity of Escherichia coli}

Peptone + citrate + glucose medium was inoculated with a suspension of Escherichia coli prepared from an agar slope and growth, citridesmolase activity (whole cells) and glucose consumption were measured at suitable time intervals. Citridesmolase activity increased whilst glucose was consumed and fell when it was exhausted (Fig. 2). It had already been observed for several cultures that activity depended on the time they remained in the incubator after cell division had ceased. At $395 \mathrm{~min}$. after inoculation the culture was transferred to the cold room $\left(4^{\circ}\right)$ for $20 \mathrm{hr}$. and then returned to $37^{\circ}$. Activity decreased in this period, but on addition of glucose was rapidly regained. 


\section{Dissimilation of citric acid}

On resuspension in an equal volume of phosphate buffer $(\mathrm{pH} \mathrm{7 \cdot 0)}$ for $30 \mathrm{~min}$. at $37^{\circ}$, cells with high activities produced no keto-acids from the citrate test medium. When $\mathrm{Na}$ citrate dihydrate $(2 \cdot 1 \%),\left(\mathrm{NH}_{4}\right)_{2} \mathrm{SO}_{4}(0 \cdot 2 \%)$ and $\mathrm{MgSO}_{4}$. $7 \mathrm{H}_{2} \mathrm{O}(0 \cdot 04 \%)$ were added to the buffer, furnishing a medium able to support growth of Aerobacter aerogenes, the activity of $\boldsymbol{E}$. coli was lost just as rapidly and no growth occurred. Losses in activity of 70-80\% occurred when $E$. coli

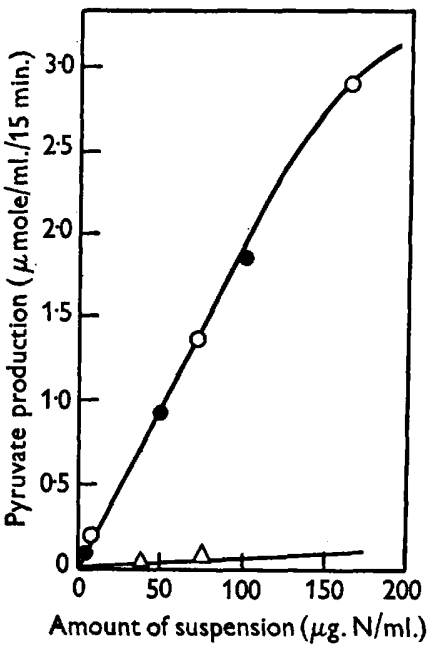

Fig. 1

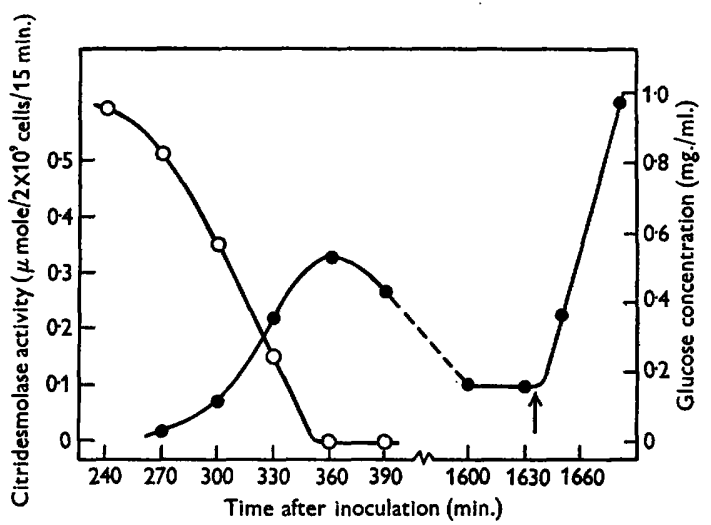

Fig. 2

Fig. 1. Relations between pyruvate production from citrate and amounts of disintegrated cell suspension of Aerobacter aerogenes in the incubation mixture. Citrate exhausted in growth, whole cells active, $O$; citrate in excess, whole cells inactive, $O$; growth in aerated glucose-mineral salt medium, whole cells inactive, $\Delta$.

Fig. 2. Development of citridesmolase activity of Escherichia coli: dependence on presence of glucose in growth medium. Activity, $\bigcirc$; glucose concentration, $O$; further glucose addition at point indicated by arrow. At $395 \mathrm{~min}$. the temperature of the culture was reduced to $4^{\circ}$ and at $1600 \mathrm{~min}$. incubation was resumed at $37^{\circ}$.

cells were washed twice with water. Cells that had lost activity by these treatments regained it completely within $30 \mathrm{~min}$. when incubated with the complete peptone + citrate + glucose medium, but not when any one of these three constituents was omitted.

Suspensions of disintegrated cells were prepared from a series of batches with different activities resulting from various incubation periods in the stationary phase. Relationships were established, as described for Aerobacter aerogenes between nitrogen content of diluted preparations and their ability to produce keto-acids from citrate (Fig. 3). The results were in sharp contrast to those obtained with $A$. aerogenes since low activity was not increased by disintegration: there was a rough proportionality between activity before and after crushing. Furthermore, when one-half of a large batch of active cells of Escherichia coli was incubated with an equal volume of buffer for $30 \mathrm{~min}$. both whole cells and those subsequently disintegrated were devoid of activity. The other half of the batch, crushed immediately after harvesting, was active 
after disintegration and an active cell-free extract was obtained from the preparation by centrifugation. The medium used in tests for activity contained $\mathrm{Mg}^{++}$ions which Dagley \& Dawes $(\mathbf{1 9 5 3} b$ ), showed to be a co-factor for citridesmolase activity in $A$. aerogenes. Gillespie \& Gunsalus (1953) showed activation of the enzyme from Streptococcus faecalis by $\mathrm{Mn}^{++}$ions, but concentrations up to $10^{-3} \mathrm{M}$ did not restore citridesmolase activity to whole or disintegrated $E$. coli cells after it had been lost by treatment with buffer.

\section{Effect of growth in glucose + citrate + mineral salt medium on subsequent develop- ment of citridesmolase activity in Escherichia coli}

Vaughn et al. (1950) concentrated on ability of Escherichia coli to decompose rather than grow on citrate since observations of growth in media containing a variety of compounds showed that 'the added compounds functioned only to provide food for the growth of the test cultures'. Measurements of citrate utilized were made after 4 days. Experiments were now conducted to ascertain whether additional growth could be observed in glucose + mineral salt media after prolonged incubation in the presence of citrate. One series of $6 \times 1$ in. Pyrex boiling tubes each contained $25 \mathrm{ml}$. of a solution (sol. A) of: $\mathrm{KH}_{2} \mathrm{PO}_{4}(0.72 \%$, w/v, $\mathrm{pH} 7) ;\left(\mathrm{NH}_{4}\right)_{2} \mathrm{SO}_{4}(0.12 \%, w / v) ; \mathrm{MgSO}_{4} .7 \mathrm{H}_{2} \mathrm{O}$ $(0.4 \%, \mathrm{w} / \mathrm{v})$; glucose to give a concentration range 0-9 mM.; similar series contained in addition Na citrate dihydrate $(0 \cdot 44 \%, \mathrm{w} / \mathrm{v})$. Determinations of growth of $E$. coli (Table 1) at $24 \mathrm{hr}$. showed no significant difference between the

Table 1. Relation between crop of Escherichia coli and glucose concentration in mineral salt medium, with and without citrate additions

\begin{tabular}{|c|c|c|c|c|}
\hline \multirow{2}{*}{$\begin{array}{c}\text { Glucose } \\
\text { concentration } \\
(\mathrm{mM})\end{array}$} & \multicolumn{4}{|c|}{ No of bacteria (millions $/ \mathrm{ml}$ ) at times indicated } \\
\hline & \multicolumn{2}{|c|}{$\begin{array}{l}24 \mathrm{hr} . \\
\text { Citrate absent }\end{array}$} & Citrate present & $\begin{array}{l}68 \mathrm{hr} . \\
\text { nt }\end{array}$ \\
\hline 0.89 & 90 & 90 & 90 & 110 \\
\hline 1.78 & 180 & 195 & 195 & $\mathbf{3 6 0}$ \\
\hline $2 \cdot 67$ & 250 & 280 & 275 & 740 \\
\hline $3 \cdot 56$ & 320 & 340 & 315 & 585 \\
\hline $4 \cdot 44$ & 395 & 390 & 390 & 700 \\
\hline $8 \cdot 89$ & 620 & 790 & 750 & 960 \\
\hline
\end{tabular}

tubes that contained citrate and those that did not, and analysis at that time showed that glucose had disappeared in all cases. On prolonged incubation, however, further slow growth occurred, which ceased after $64 \mathrm{hr}$., in cultures containing citrate. Citridesmolase was not detected in these cultures at any stage, but the presence of citrate was not without effect even during the first $24 \mathrm{hr}$. when growth occurred entirely at the expense of glucose. This is shown by the following experiment. Glucose $(0.08 \%, \mathrm{w} / \mathrm{v} ; 4.4 \mathrm{~mm}$.) was added to two $250 \mathrm{ml}$. lots of sol. A; to one lot no further addition was made and to the other $0.44 \%, \mathrm{w} / \mathrm{v}, \mathrm{Na}$ citrate dihydrate was added. After $18 \mathrm{hr}$. growth the cells were centrifuged and resuspended in an equal volume of the peptone + citrate growth medium for $E$. coli, from which glucose had been omitted. Cells re- 
moved from either batch $30 \mathrm{~min}$. after resuspension showed no activity, but $15 \mathrm{~min}$. after adding $1 \mathrm{~g}$. glucose $/ \mathrm{l}$. to each an increase in activity was detected for those cells which had grown in the presence of citrate (Fig. 4). For those grown without citrate there was a lag period and the maximum activity attained was less. This was confirmed in experiments using different glucose concentrations in the peptone + citrate + glucose medium and the results are given in Table 2. Clearly growth in mineral salt medium in the presence of citrate, although not conferring measurable citridesmolase activity, enabled a given amount of glucose in peptone medium to produce subsequently a greater activity in the cells.

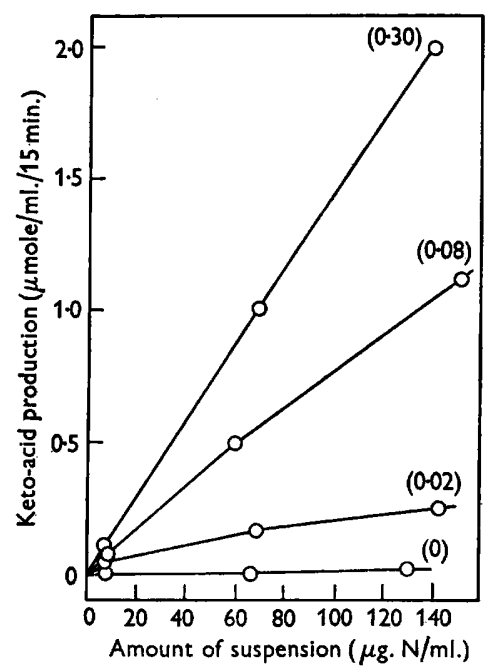

Fig. 3

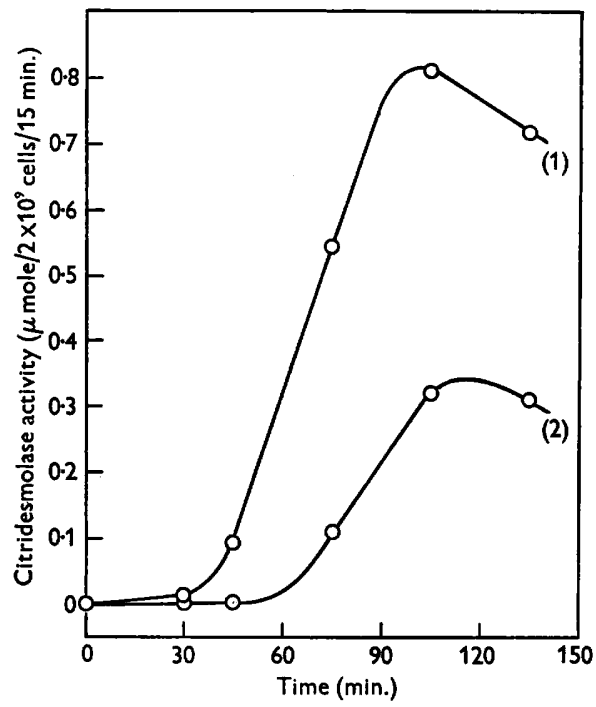

Fig. 4

Fig. 3. Relations between keto-acid production from citrate and amounts of disintegrated cell suspension of Escherichia coli in the incubation mixture. Figures in brackets give activities ( $\mu$ mole keto-acid $/ 2 \times 10^{9}$ cells $/ 15 \mathrm{~min}$.) of whole cells before crushing.

Fig. 4. Effect of addition of citrate to a glucose + mineral salt growth medium on citridesmolase development in Escherichia coli. After growth, cells were suspended in peptonecitrate medium to which glucose was added at 30 min. and development of activity followed with time. Citrate present during growth in glucose + mineral salt medium, (1); no citrate present, (2).

Table 2. Dependence of citridesmolase development on glucose concentration

Escherichia coli grown in glucose + mineral salt medium, with or without addition of citrate, and transferred to peptone + citrate media containing various concentrations of glucose. The maximum activity (see Fig. 4) was then measured in each case.

$\begin{array}{ccc}\begin{array}{c}\text { Glucose } \\ \text { concentration } \\ \text { (g./l.) }\end{array} & \text { Maximum activity }\left(\mu \mathrm{mole} / \mathbf{2} \times \mathbf{1 0}^{\mathbf{9}} \text { cells } / \mathbf{1 5} \mathrm{min} .\right) \\ 0 \cdot 0 & \text { Citrate present } & \text { Citrate absent } \\ 0 \cdot 2 & 0 \cdot 00 & 0 \cdot 00 \\ 0 \cdot 4 & 0 \cdot 05 & 0.00 \\ 0 \cdot 6 & 0 \cdot 25 & 0.02 \\ 0 \cdot 8 & 0.53 & 0 \cdot 07 \\ & 0 \cdot 83 & 0 \cdot 30\end{array}$




\section{Products of citridesmolase action}

Cell-free extracts of Aerobacter aerogenes dissimilate 1 mole of citrate to 1 mole each of pyruvate, $\mathrm{CO}_{2}$ and acetate; 1 mole of oxaloacetate is formed initially but the preparations contain a powerful oxaloacetate decarboxylase (Dagley \& Dawes, $1953 \mathrm{~b}$ ). To each of a series of tubes containing $2.5 \mathrm{ml}$. of phosphate buffer $\left(\mathrm{KH}_{2} \mathrm{PO}_{4}, 0.5 \% ; \mathrm{pH} 7\right)$ and 0-3.5 $\mu$ mole citrate $/ \mathrm{ml}$. was added $0.5 \mathrm{ml}$. of an active disintegrated suspension of Esherichia coli. After $10 \mathrm{~min}$. incubation total keto-acid concentrations were determined and the values plotted against added citrate (Fig. 5). The slope of the linear part of the curve

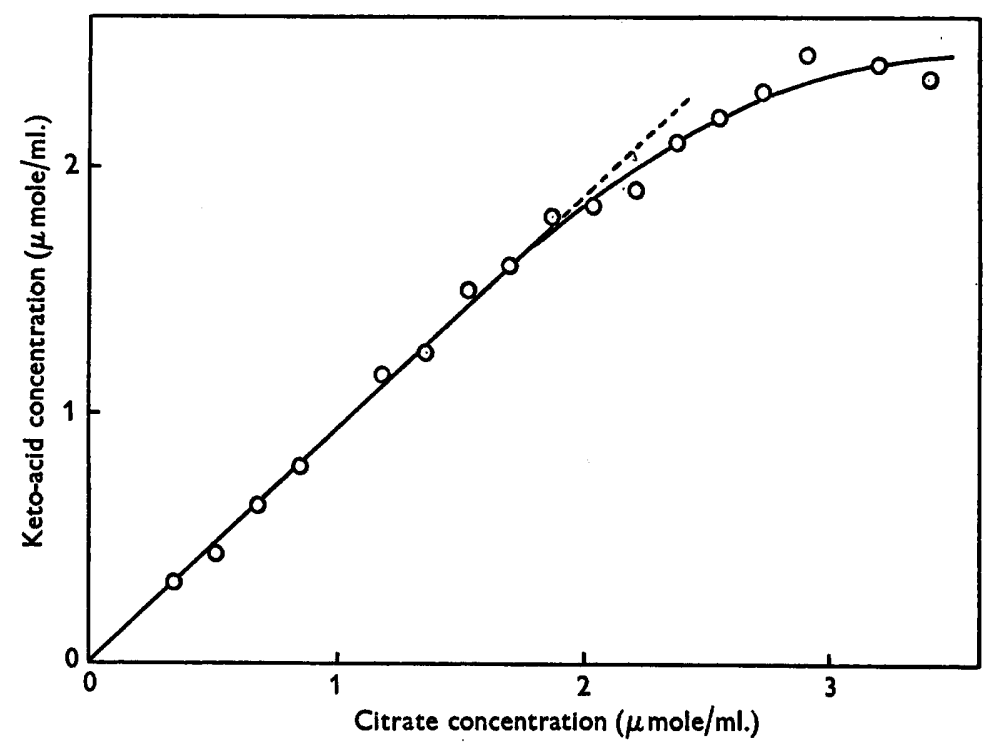

Fig. 5. Production of keto-acids from various concentrations of citrate by a suspension of disintegrated Escherichia coli.

gives a citrate: keto-acid ratio of 1.06. Extraction and chromatography of the 2:4-dinitrophenylhydrazones using the solvents of Dagley et al.(1952) and of Virtanen et al. (1953) gave well-defined spots corresponding to oxaloacetate ( $\boldsymbol{R}_{F}$ values 0.25 and 0.8 in the two solvents, respectively) in addition to weaker spots corresponding to pyruvate. When fluids were deproteinized after action of the disintegrated cells and held at $100^{\circ}$ for $15 \mathrm{~min}$. before 2:4-dinitrophenylhydrazone formation, the spot of $R_{F}$ value 0.25 disappeared and gave place to the two spots for pyru vate of which the slower-moving was most distinct. Similar fluids treated with aniline citrate in a Warburg respirometer evolved c. $0.8 \mu$ mole $\mathrm{CO}_{2} / \mu$ mole keto-acid estimated as 2:4-dinitrophenylhydrazone. Suspensions of disintegrated $\boldsymbol{E}$. coli showed very little oxaloacetate decarboxylase activity. 


\section{DISCUSSION}

The results for Aerobacter aerogenes present certain marked contrasts to those for Escherichia coli. Glucose inhibited citridesmolase development in the former when growing in a citrate + mineral salt medium (Dagley \& Dawes, $1953 a$ ), whereas activity of $E$. coli increased during glucose consumption and decreased when glucose had disappeared. Further, this loss of activity persisted when the cells were disintegrated while differences in activity for $A$. aerogenes grown in citrate media without aeration were abolished by crushing. Accumulation of acetate in growing cultures of $A$. aerogenes has been associated with the concomitant loss of citridesmolase activity (Dagley \& Daws, $1953 a$ ); acetate may inhibit transport of citrate to its site of action within the cell. Relevant to this suggestion are the conclusions of Barrett, Larson \& Kallio (1953) that a carrier system is involved in citrate transport, and those of Kogut \& Podoski (1953) that such a system may be developed adaptively (by induction).

The labile nature of the citridesmolase of Escherichia coli and its rapid reactivation only when complete peptone + citrate + glucose medium is used may be related to one view of enzyme synthesis discussed by Spiegelman \& Halvorson (1953). Their results suggest that if an enzyme precursor is formed it may become active enzyme only with participation of the free amino acid pool, i.e. precursor + free amino acids $\rightarrow$ enzyme. Although $E$. coli growing in mineral salt medium can clearly synthesize all the amino acids it requires to form protein, the amino acid pool is relatively small (Taylor, 1947) and the enzyme system may possibly not be activated unless preformed amino acids are supplied externally. Some of the present findings offer a parallel to those of other workers concerning the formic hydrogenlyase of $E$. coli (Lascelles 1948; Billen \& Lichstein, 1951; Pinsky \& Stokes, 1952). The speculation may be made that for citridesmolase formation in $E$. coli the above reaction proceeds rapidly from left to right only in the presence of glucose as energy source and that when this is no longer available, and particularly when cells are placed in a mineral salt medium, there is a readjustment in the reverse direction as the concentrations in the free amino acid pool decrease. Our results suggest, but do not establish, that enzyme precursor may be formed during growth on glucose in mineral salt medium containing citrate, since the maximum activity acquired by these cells for a given amount of glucose present in the peptone + citrate + glucose mixture is greater than when citrate is omitted from the mineral salt medium (Table 2). Alternatively, the former cells may become permeable to citrate during growth, thereby permitting a more rapid development of enzyme in the activation test. Immediate activation was indeed found, whereas cells grown in the absence of citrate showed a lag period, but without postulating precursor formation it is difficult to account for the greater amounts of enzyme given per unit quantity of glucose in one case than the other. Further, the data for disintegrated cells appear to exclude a mechanism based on cell-permeability as the cause of differences in activity between different batches of $\boldsymbol{E}$. coli. In contrasting 
E. coli with Aerobacter aerogenes it may also be relevant to observe that not only is the latter able to grow in a citrate + mineral salt medium but also develops therein strong formic hydrogenlyase without addition of preformed amino acids (Dagley \& Dawes, $1953 a$ ).

It is a pleasure to acknowledge the skilful technical assistance of Mrs M. Lees and the co-operation of $\mathrm{Dr} A$. R. Johnson in the early stages of the work.

\section{REFERENCES}

Barrett, J., Larson, A. \& Kallio, R. (1953). The nature of the adaptive lag of Pseudomonas fluorescens toward citrate. J. Bact. 65, 187.

Billen, D. \& Lichstein, H. C. (1951). Nutritional requirements for the production of formic hydrogenlyase, formic dehydrogenase, and hydrogenase in Escherichia coli. J. Bact. 61, 515.

Brewer, C. R. \& Werkman, C. H. (1939). The anaerobic dissimilation of citric acid by Aerobacter indologenes. Enzymologia, 6, 273.

Dagley, S. \& Dawes, E. A. (1953a). Citric acid metabolism of Aerobacter aerogenes. J. Bact. 66, 259.

Dagley, S. \& Dawes, E. A. (1953b). Dissimilation of citric acid by bacterial extracts. Nature, Lond., 172, $\mathbf{3 4 5}$.

Dagley, S., Dawes, E. A. \& Morrison, G. A. (1950). Inhibition of growth of Aerobacter aerogenes: the mode of action of phenols, alcohols, acetone and ethyl acetate. J. Bact. 60, 369.

Dagley, S., Fewster, M. E. \& Happold, F. C. (1952). The bacterial oxidation of phenylacetic acid. J. Bact. 63, 327.

Friedemann, T. E. \& Haugen, G. E. (1943). Pyruvic acid. II. The determination of keto-acids in blood and urine. J. biol. Chem. 147, 415.

Gillespie, D. C. \& Gunsalus, I. C. (1953). An adaptive citric acid desmolase in Streptococcus faecalis. Bact. Proc. p. 80.

Grunberg-Manago, M. \& Gunsalus, I. C. (1953). Aerobic and anaerobic citric acid metabolism of Escherichia coli. Bact. Proc. p. 73.

Hughes, D. E. (1951). A press for disrupting bacteria and other micro-organisms. Brit. J. exp. Path. 32, 97.

Isherwood, F. A. \& Cruickshank, D. H. (1954). Chromatographic separation and analysis of mixtures of pyruvic, oxalacetic and alpha-ketoglutaric acids. Nature, Lond., 173, 121.

Kogut, M. \& Podoski, E. P. (1953). Oxidative pathways in a fluorescent Pseudomonas. Biochem. J. 55, 800.

Koser, S. A. (1924). Correlation of citrate utilization by members of the colonaerogenes group, with other differential characteristics and with habitat. J. Bact. 9, 59.

LARA, F. J. S. \& Stokes, J. L. (1952). Oxidation of citrate by Escherichia coli. J. Bact. 63, 415.

LASCELLES, J. (1948). Studies on formic hydrogenlyase in Escherichia coli. Biochem. $J .43$, vi.

Lominski, I., Conway, N. S., HaRPer, E. M. \& RenNie, J. B. (1947). Utilization of citric acid by some so-called citrate-non-utilizing bacteria. Nature, Lond., $160,573$.

Pinsky, M. J. \& Stokes, J. L. (1952). Requirements for formic hydrogenlyase adaptation in nonproliferating suspensions of Escherichia coli. J. Bact. 64, 151.

Somogyı, M. (1937). A reagent for the copper-iodometric determination of very small amounts of sugar. J. biol. Chem. 117, 771 .

Spiegelman, S. \& Halvorson, H. O. (1953). The nature of the precursor in the induced synthesis of enzymes. Symp. Soc. gen. Microbiol. 3, 98. 
Stern, J. R. \& OchoA, S. (1951). Enzymatic synthesis of citric acid I. Synthesis with soluble enzymes. J. biol. Chem. 191, 161.

TAYLOR, E. S. (1947). The assimilation of amino-acids by bacteria. 3. Concentration of free amino-acids in the internal environment of various bacteria and yeasts. J. gen. Microbiol. $1,86$.

Umbreit, W. W., Burris, R. H. \& STAuffer, J. F. (1945). Manometric Techniques and related Methods for the Study of Tissue Metabolism. Minneapolis, Minn: Burgess.

VARLey, H. (1954). Practical Clinical Biochemistry, p. 141. London: Heinemann.

Vaughn, R. H., Osborne, J. T., Wedding, G. T., Tabachnick, J., Beisel, C. G. \& Braxton, T. (1950). The utilization of citrate by Escherichia coli. J. Bact. 60, 119.

Virtanen, A. I., Miettinen, J. K. \& Kunttu, H. (1953). Alpha-ketoacids in green plants. Acta chem. Scand. 7, 38.

(Received 14 April 1954) 